\title{
Regional Development Theory and Its Instructions for Regional Culture Industry Development
}

\author{
QU Jiang-bin \\ The Student Department \\ Hebei University \\ Baoding, Hebei Province, China \\ qjbhbu@163.com
}

\author{
MA CE \\ College of Economics \\ Hebei University \\ Baoding, Hebei Province, China \\ liuweiqjb@163.com
}

\begin{abstract}
The regional development theory in western countries has been 170 years. It is a certain reference function for regional development planning in China. Culture industry is a kind of recently emergent industries in China The application of western regional development theory on the practice of regional culture industry in China is a new research topic.The paper takes the regional development theory as a starting point for research and combined it with the situation of Chinese regional culture industry development. Finally, the paper draws the Instructions from the western regional development theory to Chinese regional culture industry development
\end{abstract}

Keywords-regional development theory; culture industry; growth pole; isostatic increase theory; industry cluster theory

\section{THE BASIC THEORIES OF REGIONAL DEVELOPMENT THEORY}

The formation of regional development theory can be traced back to the early location theory. The scientific regional development theory was emerged in Europe after the Second World War.Generally, regional development theory has experienced four stages.

\section{A. Location Theory}

The representative location theories mainly consist of agricultural location theory established by Thanen and industrial location theory established by Weber. In 1826, the German economist named Johann Heinrich von Thunen finished The Isolated State in Relation to Agriculture and Political Economy.This book is the first masterpiece on classic location theory in the world. According to the relationship between agriculture and market in Germany,Thunen studied the allocation of production in the isolated state and put forward the famous agricultural location theory model.He not only found out agricultural zoning phenomenon caused by different of land prices ,but also fully discussed the allocation of the agriculture,the forestry, animal husbandry and the industry. From the point of view of the modern regional development theory, these ideas that Thunen put forward in more than 100 years ago have great influence on the development of location theory. Alfred Weber, the other German economist, established a rounded theoretical system for the industrial location theory. In 1909, Theory of the Location of Industries was published.Alfted Weber put forth the first developed general theory of industrial location.The core idea of industrial location theory is that production site is determined by the location factors and enterprises will be attracted to the place with the least location manufacturing expenses.

\section{B. Central Place Theory}

Central place theory extended the research on the inchoate regional development theory from the field of production to the field of market. This theory was established by W.Christaller and A.Losch. Deeply influenced by location theory, central place theory is one of theoretical basises of regional economics. This theory put forward the concept of "central place" and probed into the relationship between central place and hinterland. Central place theory is of great significance to the study of the regional structureand and still has certain theoretical reference in the regional planning today.

\section{The Scientific Regional DevelopmentTheory}

Regional economic development theory with the core of regional economic growth was widely developed and perfected after the Second World War. The representative theories mainly consist of balanced development theory and unbalanced development theory.

1) Balanced Development Theory:It was originated in the nineteen forties. The representative theories mainly consist of "the theory of the big-push" established by P.N.Rosenstein-roda and "vicious circle of poverty" established by Ragnar Nurkse. The opinion of balance development theory is that with the production elements of the interregional flow, regional economy development level will tend to balance, so that productive force and investment should be allocated to each region in equilibrium and the balanced development of regional economic can be realized. An United States economist named Williamson put forward "Inverted-U Theory"[1] the basis of the statistical analysis based on the change of regional income differences in some developed countries.This theory is the most influential view on balance development theory. It points that the gap of regional economic development in the course of economic development cycle will shrink. In the early stage of economic development, balance development theory was more reasonable and practical significance to developing countries. 
2) Unbalanced Development Theory: The opinion of unbalance development theory is that the regional development gap will not shrink, on the contrary, it will expand. [2]The representative theories mainly consist of "growth pole" raised by Francois Perroux, "cumulative causation model" raised by Karl Gunnar Myrdal and "Gradient elapse theory" raised by R. Vernon. The opinion of "growth pole" is that some leading industries or innovative capacity of enterprises or industries are concentrated in specific region or large city with the regional capital and technology are highly concentrated, thus, growth pole is formed. The growth pole can produce strong radiation effects on the adjacent areas of growth pole. The opinion of "cumulative causation model" is that the natural role of market forces in any time will increase domestic and international inequality as long as the overall level of development is low. [3] "Gradient elapse theory" put forward that each country or region in the development of the gradient will transfer from high gradient zone to low gradient zone over time.

\section{The Innovation of Regional Development Theory}

Since the nineteen eighties, with the intensive study on regional development,some new regional development theories have been formed. We only select the two representative theories ssociated with the central argument.

1) Industry Cluster Theory: This theory was established by Michael Porter, the famous American scholar, in nineteen ninties. The connotation of industry cluster theory is that some interconnected companies, suppliers, related industries and specialized institutions come together in a group in a particular region and form effective market competition, regional agglomeration effect,scale effect and external effect according the regional cluster.

2) Regional Sustainable Development Theory: Regional sustainable development theory was emerged with the worsening of the global environment. The idea of sustainable development appeared in ancient times, but as a modern development theory, its direct theoretical source is the opinions of Club of Rome. The German scholar named Albert Schmid pointed out in 1995 that it is the most important for regional development planning based on the possibility and the necessity of sustainable development to formulate regional development goal according with the inherent characteristics of the region and pay attention to the natural environment. Compared with the traditional study of regional development, regional sustainable development theory emphasizes coordination of the relationship among population, resource, environment and development. This theory not only advocates the equilibrium among social goals, economic goals and ecological objectives, but also lays stress on the complexity and wholeness of development process.

\section{The CURRENT Situation OF REgional CUlture INDUSTRY DEVELOPMENT IN CHINA}

As a strategic recently emergent industry, regional culture industry has become an important force to change the mode of regional economic growth and promote the regional scientific development in China. Regional culture industry is the result of comprehensive development between regional economy and regional culture. The development level of regional culture industry is not only the performance of a regional economic development level, innovation ability, the level of science and technology and sustainable development ability, but also the directly reflect of culture influence power and mental control force. Consistent with the unbalanced economic development situation in the East, the West and the Midland, the development level of culture industry in China also exists in a large regional unbalanced development situation.

\section{A. The Current Situation of Culture industry in the East}

The East has a higher economic development level, so its culture industry development is relatively mature to other regions in China. [4]The phenomenon which culture industry belt distribute by means of the city group is more prominent. At present, the East has formed three major cultural industrial belts: Yangtze River Delta, Pearl River Delta and Circum-Bohai-Sea region. The East has become the most developed region on culture industry in China, and the reason can be summarized as follows:

1) Solid economic foundation. The economic development of the East started earlier, the economic development level is high. The strong economic strength can provide funding, technology and personnel for culture industry. The rapid economic progress promotes the East resident's disposable income increased. The stronger consuming ability of the East resident on cultural products plays an important role in promoting the development of culture industry.

2) Perfect market mechanism. The East has formed a set of perfect market system. The integration of all resources in the operation of the market mechanism has formed the cultural production system to meet the market demands. The rapid development of culture industry can form a series of new social resources according to the operation of the market mechanism.

3) Aggregation of cultural talent. Due to the Developed economy and many Colleges and universities gathering, a lot of cultural talents can be provided for the development of culture industry in the East. The governments in the East attach great importance to the development of culture industry and introduce preferential policies to attract cultural talent.

\section{B. The Current Situation of Culture industry in the Midland}

The Midland is rich in historical and cultural resources and has deep cultural heritage. The Midland is inferior to the eastern region in the economic strength and talent resources. Although the culture industry of the Midland is in the second position in China, several characteristic culture industry regions have been initially formed. The characteristic culture industry regions mainly include: Central Plains Culture of Henan Province, Xiang-Chu Culture of Hunan Province and Hubei Province, Red Culture and Taoism culture of Jiangxi 
Province,Jin Culture of Shanxi Province and Hui culture of Anhui Province. At present, the focus of culture industry development in the Midland is the entertainment industry, the film industry and the tourism.

\section{The Current Situation of Culture Industry in the West}

The West with much land and few people is rich in resources .Minority nationalities gathered in this region. Ecological culture and national culture in the West shows diversity. Due to geographical and historical reasons, the economy development in the West started late and economic marketization degree is lower than other regions in China. The weak of economic strength leads the culture industry development in the West to be lack of funds and the level of utilization of cultural resources is lower. The culture industry development in the West lags behind other regions of China. With the implementation of the western development strategy, the western region culture industry has obtained great development opportunity. Governments at all levels provide the necessary financial and policy support for cultural development of the West, so the culture industry in the West has made certain progress.

\section{COUNTERMEASURES OF REGIONAL CULTURE} INDUSTRY DEVELOPMENT IN CHINA BASED ON REGIONAL DEVELOPMENT THEORY

\section{A. Use Regional Sustainable Development Theory to Realize Sustainable Development of Regional Culture Industry}

If we use regional sustainable development theory to promote the sustainable development of culture industry, it is necessary that the development planning of regional culture industry should not only take the economic growth as the goal, but also think highly of social effect and ecological environment. The realization of regional culture industry planning adapting to the regional development, we should pay attention to the following three aspects:

1) The sustainable use of regional cultural resources. We should protect and develop the non-renewable cultural resources. The development of cultural resources with Protection not only can bring considerable economic benefits, but also can inherit the outstanding human culture

2) The sustainable manufacture of regional cultural product. Sustainable manufacture of regional cultural product is the core of realizing the sustainable development of regional culture industry. Sustainable manufacture of regional cultural product should be rooted in the soil of regional culture and unearth the deep connotation of regional culture.

3) The sustainable development of regional cultural market. Industrial development is inseparable from the market, so the regional cultural market development can promote regional culture industry mature gradually. The sustainable development of the regional cultural market should pay attention to the following three aspects: The fist is the combination with the consolidation of the domestic market and the expansion of overseas market; The second is the combination with the consolidation of the native market and the expansion of other regions market in China; The third is the combination of city market and rural market.

\section{B. Use Unbalanced Development Theory to Perform the Gradual Strategy of Culture Industry Development}

Unbalanced development theory has been used in the development of regional economy in China and has achieved remarkable results. Regional culture industry also can be based on unbalanced development theory. Cultural industry development in each region still has existed difference in many aspects, such as the market level, economic strength, technology and management level, therefore, regional cultural industry development should take "growth pole"and "Gradient elapse theory" as the guidance in the initial stage. The production factors of culture industry should be gathered in the regions with the highest efficiency in productivity layout. The allocation of productive force on culture industry should also take focus on these regions. These regions can be cultivated to be the growth pole of cultural industry. The growth pole of cultural industry should strengthen itself as soon as possible and drive the backward regions to develop together according to the transfer of production factors.

\section{Use Balanced Development Theory to Properly Handle the Development Disparity of Regional Culture Industry}

Regional development disparity is inevitable and will exist over a long period of time with regard to a country with much land and a large population. In the background of the globalization, the connection of the various elements among the regions is so close that the construction and development of any regions will have an impact on other regions. Only if the regional coordinated development strategy should be carried out for culture industry, cultural industry of the whole country can make progress and the national cultural soft power will enhance. According to balanced development theory, regional culture industry development should break through the bondage from the traditional concept on administrative boundaries and must attach importance to the overall interests of the region to promote the coordinated development of regional culture industry.[5] Governments at all levels should introduce the preferential policies to the cultural industry of the West and innovate the market mechanism of culture industry development of the Western to realize the optimal allocation of cultural resource. A series of preferential taxation and financial policies should be put into effect to improve the investment environment and business environment of the culture industry to attract more social forces to invest in the culture industry of the West and the Midland.

\section{Use Industry Cluster Theory to Develop Culture Industry Cluster in China}

Regional cooperation in culture industry and culture industry cluster should be the important strategy to promote the development of cultural industry. As an important part of the sustainable development strategy, culture industry cluster can promote the upgrading of the industrial structure of China in response to the current international financial crisis. We should explore the actual application value of the 
industrial cluster theory in the development of regional culture industry cultivate the cultural industry cluster to be an important development mode of regional culture industry in China. At present, there is the positive spatial correlation in the regional culture industry development in China. That is to say the regional cultural industry has a positive spillover effect in space. Each region should strengthen the cooperation with the adjoining areas on culture industry to promote the establishment and development of the regional culture industry cluster. Governments at all levels should reduce the cultural communication barriers among adjacent areas caused by subjective factors to achieve the regional integration strategy of the culture industry. If the culture industry cluster is set up, the culture industry cluster can drive regional culture industry development and regional culture industry development can also realize the core function of culture industry cluster.

\section{ACKNOWLEDGMENT}

The research is supported by The National Statistics Research Project of National Bureau of Statistics of China (Grant No. 2012LY094).

\section{REFERENCES}

[1] Williamson J G, "Regional inequalities and the process of national development” ,Economic Development and Cultural Change, vol. 13, Chicago :University of Chicago Press, 1965, pp. 1-84.

[2] Ding Huanfeng, "Review of Regional Development Theory", Productivity Research ,vol.1, 2005, pp. 226-228

[3] Gunnar Myrdal, Economic theory and under developed regions, London: Duckworth, 1957.

[4] LIANG JUN and CHEN Xianjun, "Research on the region differentiation of culture industry development in China” ,Economic Review, vol.4, 2012, pp. 63-65.

[5] WEI Liangliang and TU Meizeng, "Western Regional Development Theory and its Instructions for China Regional Development", JournaI of Anhui Agri. Sci, vol. 33,2005, pp. 531-532. 